\title{
Peptic ulceration affecting the left ventricle
}

\author{
A KENNEDY \\ From the Department of Histopathology and Cytology, Northern General Hospital, Sheffield
}

Large peptic ulcers affecting the cardiac chambers are unusual but at least 11 cases have been recorded. Penetration of the pericardium or great vessels is less rare; Prolla et $a l^{1}$ found 22 such cases and more recent examples have been reported by Monro et $a l^{2}$ and by Caspi et al.$^{3}$ Penetration of a coronary artery was reported by Matthews. ${ }^{4}$ Given that there may be many similar cases which are never reported it seemed worth reviewing the main features of peptic ulceration affecting the myocardium and describing another case.

\section{Case report}

The patient was an 81-year-old blind woman who lived in reduced circumstances. One week before her death she had fallen and lacerated her scalp. Her general practitioner then found that her haemoglobin concentration was only $5.3 \mathrm{~g} / \mathrm{dl}$, with a red cell count of $2.47 \times 10^{12} /$. The mean cell haemoglobin concentration was $30.6 \mathrm{~g} / \mathrm{dl}$. The white cell count was $14.9 \times 10^{9} / 1$, with $12.97 \times 10^{9} / 1$ polymorphonuclear leucocytes and $1.05 \times 10^{9} / 1$ lymphocytes. The blood film showed changes of iron deficiency. Because of these findings and her neglected state she was admitted to hospital. Her only specific complaint was of feeling faint and dizzy.

On examination she was pale and cold, with a temperature of $33.6^{\circ} \mathrm{C}$, and showed signs of neglect. There were crepitations at the lung bases. The pulse was regular at 80 beats/min and the blood pressure was $100 / 40 \mathrm{~mm} \mathrm{Hg}$. There was no evidence of cardiac failure and the only important finding was the presence of black faeces in the rectum. No abnormality was reported in a supine chest radiograph.

She was regarded as having bronchopneumonia associated with chronic blood loss, hypothermia, and neglect. Despite supportive treatment she died eight hours after admission.

Necropsy was carried out nine hours after death. There was slight ankle oedema but no koilonychia. No important abnormality was found in the head or neck. There were small bilateral pleural effusions. There was a little pulmonary oedema but no evidence of infection or embolism Death was due to massive gastrointestinal haemorrhage. The stomach contained fresh blood and altered blood was

Address for reprint requests: Dr A Kennedy, Department of Histopathology and Cytology, Northern General Hospital, Sheffield S5 7AV.

Accepted 1 January 1983 present throughout the bowel. Otherwise the intraabdominal organs were unremarkable.

The source of the bleeding was a large peptic ulcer $3 \mathrm{~cm}$ in diameter in the anterior wall of the stomach in a large sliding hiatal hernia about $7 \mathrm{~cm}$ in diameter. The ulcer had penetrated the pericardium and the pericardial cavity was obliterated by adhesions. The ulcer had invaded the myocardium of the left ventricle high up on the inferior surface (fig 1). The floor of the ulcer was in the form of a shallow cone, at the apex of which there was a small perforation into the ventricle (fig 2 ). The general form of the ulcer was typical of peptic ulceration and there was no evidence of tumour. Histological examination confirmed that the ulcer was benign and that it had arisen in gastric mucosa in the hiatal hernia. The surrounding mucosa appeared healthy, with a well-developed layer of parietal

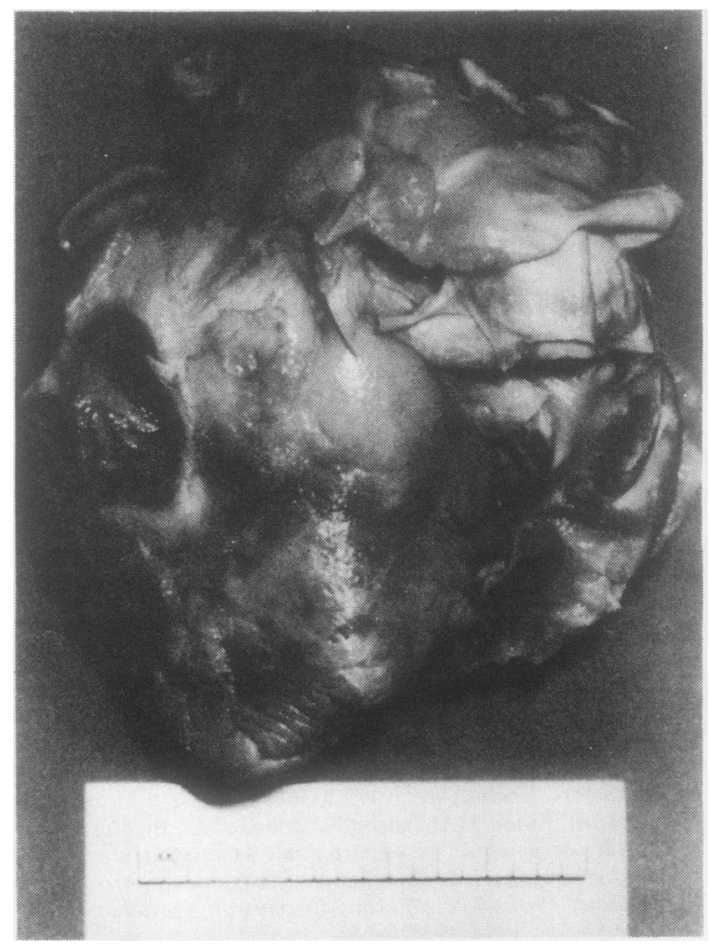

Fig 1 Posterior surface of the heart after the adherent hiatal hernia had been dissected away; the floor of a large ulcer is situated near the atrioventricular sulcus. 


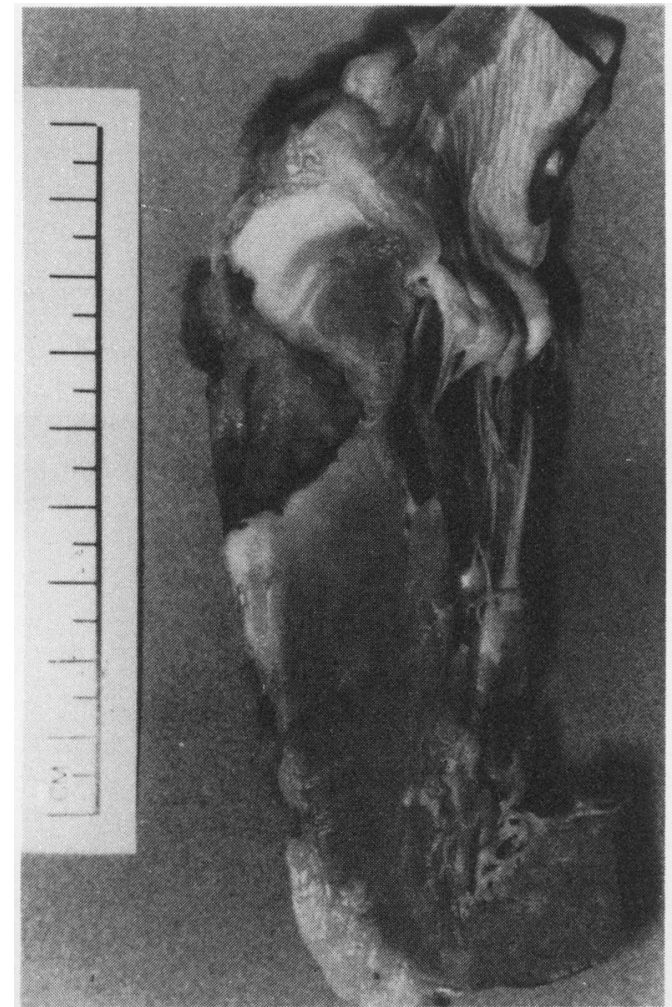

Fig 2 Longitudinal section through the posterior wall of the left ventricle; a probe could be passed from the apex of the conical ulcer into the ventricle.

cells. The floor of the ulcer was lined with slough. There was fibrosis and endarteritis obliterans in the underlying myocardium. The heart itself weighed $520 \mathrm{~g}$ and the only important finding other than the perforation was left ventricular hypertrophy. There was no evidence of an islet-cell tumour of the pancreas.

\section{Discussion}

Nickels ${ }^{5}$ reported what he thought to be the first case of a peptic ulcer penetrating the heart but Prolla et al ${ }^{1}$ had found nine cases in published reports dating back to 1880 . Of these they accepted seven and added a further case of their own. Since then cases have been reported by Itabashi and Granada ${ }^{6}$ and by Di Bonito and Bianchi, ${ }^{7}$ so the present case is at least the twelfth to be published. Several features are common to many of the published casesnotably the clinical circumstances, the site and nature of the ulcer, the cardiac chamber affected, and the mode of death.

In most of the published cases the patient has been an elderly or middle-aged woman; often there has been a long history of oesophageal reflux or symptoms of ulcer. The lesion may, however, occur in younger people, the most notable example being the patient of Itabashi and Granada, ${ }^{6}$ who was a mentally handicapped man of 23 .

Although malignant disease is common in the region of the lower oesophagus and gastric cardia and tumours may affect the pericardium, perforation of the cardiac chambers seems to have been recorded only in the case of "benign" peptic ulcers. The ulcers have often been large and have been $1.3-6 \mathrm{~cm}$ in diameter. Usually they have occurred in a hiatal hernia, which may account for the predominance of elderly women. They may, however, occur in the oesophagus itself or in the lesser curvature of a normally sited stomach.

The site of perforation of the heart has usually been the left ventricle but the left atrium may be affected. ${ }^{16}$ In the case described by Prolla $e t$ al ${ }^{1}$ the patient had received deep $x$-ray treatment. Other major vascular sites to be affected in the thorax include the coronary arteries, ${ }^{4}$ the aorta ${ }^{89}$ and the pulmonary artery. ${ }^{4}$

Most patients have died of massive gastrointestinal haemorrhage but in one case in which the left atrium was affected there was the bizarre feature of systemic food embolism. ${ }^{6}$ Matthews operated successfully on the patient whose coronary artery was affected but the patient died five days later from ventricular fibrillation. ${ }^{4}$ Macarthur operated successfully on an oesophagoaortic fistula, ${ }^{9}$ but curative surgery was not attempted in the remaining cases.

I am indebted to Dr H Pilling, HM Coroner, for permission to publish this case. The photography is the work of the Department of Medical Illustration, Northern General Hospital, and Mrs Linda Norcliffe typed the manuscript.

\section{References}

' Prolla JC, Taebel DW, Kirsner JB. Perforation of an oesophagogastric anastomotic ulcer into the left atrium. Case report and review of the literature. Gastroenterology 1967;52:871-4.

2 Monro JL, Nicholls RJ, Hately W, Murray RS, Flavell G. Gastropericardial fistula-a complication of hiatus hernia. $\mathrm{Br} J$ Surg 1974;61:445-7

${ }^{3}$ Caspi G, Delignieres S, Guerre J. Une complication exceptionelle de la hernia hiatale: la rupture dans le péricarde. Sem Hôp Paris 1977;53:1714.

4 Matthews HR. Haematemesis from a coronary artery caused by penetration of a gastric ulcer in a hiatus hernia. $\mathrm{Br}$ Heart $J$ 1974;36:1141-3.

5 Nickels J. Peptic ulcer in hiatus hernia penetrating the heart. Br J Dis Chest 1974;68:273-8.

- Itabashi HH, Granada LO. Cerebral food embolism secondary to oesophageal cardiac perforation. JAMA 1972:219:373-5.

' Di Bonito L, Bianchi C. Una rara complicazione dell' ernia iatale: perforazione di un'ulcera dello stomaco intratoracico nel ventriculo sinistro. Minerva Chir 1978;33:667-9.

- Sabety AM, Franklin PG. Gastro-aortic fistula-report of a case. Dis Chest 1968;53:783-4.

- Macarthur AM, Wright JEC. Complications of intrathoracic gastric ulcer associated with hiatus hernia: a description of five cases. Br J Surg 1969;56:161-4. 